\title{
Enlightenment of Marxist Social Science Methodology to Party History Education in Institutions of Higher Learning
}

\author{
Jiyu Shen ${ }^{1}$ \\ ${ }^{1}$ School of Marxism, China Jiliang University, Hangzhou 310018, China \\ *Corresponding author. Email: 1652932796@qq.com
}

\begin{abstract}
The main purpose of this paper is to better improve the practical effect of party history education in colleges and universities. Marxist social science methodology, as a scientific principle and methodology system proposed for social history institutes, combines the Marxist social science methodology with the party history education in colleges and universities in the process of party history teaching, which has a certain enlightenment effect on the current party history education in colleges and universities. The innovation of this paper lies in the entry point; based on the principles and specific methods of Marxist social science methodology and guided by its internal methodology, it adopts innovative ways and means of party history education in colleges and universities, to cultivate students' firm ideals and beliefs and political stance, and promote further development of ideological and political education in colleges and universities.
\end{abstract}

Keywords: Social science methodology, Marxist social science methodology, Party history education in colleges and universities, Ideological and political education.

\section{INTRODUCTION}

2021 marks the 100th anniversary of the founding of the Communist Party of China (CPC). Since the 18th National Congress of the CPC, the CPC Central Committee with Comrade Xi Jinping as the core has been attaching great importance to inheriting and carrying forward the glorious history of the CPC that not only refers to development history of the CPC, but also the development history of China and the struggle history of the Party and all Chinese people. President Xi Jinping emphasized that: "It is necessary to learn history to become reasonable and confident and to uphold the supreme good of moral and practice diligently. We shall learn the Party history, understanding concepts, bring tangible benefits and create a new situation." [1] It is the key content of the current ideological and political education in institutions of higher learning to learn the Party history and give full play to its role in education. Marxist social science methodology is closely linked to Party history education, runs through the whole implementation process of Party history education and offers a scientific logical thinking method for the Party history education. So, Marxist social science methodology can guide the Party history education work in institutions of higher learning in terms of education method, which is deemed as an important way for the institutions of higher learning to promote the Party history education in an effective manner.

\section{PRESENT SITUATION OF PARTY HISTORY EDUCATION IN COLLEGES AND UNIVERSITIES}

\subsection{Main Contents of Party History Education in Colleges and Universities}

Party history learning and education refers to the learning of the history of the CPC, to exert a certain influence on the educatee in the process of learning of Party history [2]. The Notice on Carrying out Party History Learning and Education for All the Party Members issued by the Central Committee of the CPC described the contents that it is necessary to carry out the Party history learning and education, thoroughly study and understand President Xi Jinping's important speeches on the Party history, and guide the majority of the Party members to keep in mind the glorious 100 
year struggle history of the CPC. Therefore, the main contents of the Party history education offered in institutions of higher learning shall include review of the 100-year history of the CPC, learning of important speeches on the Party history and summarization of the historical experience of the CPC, so that the students can learn experience from history, have a proper understanding of the important historical events and historical figures in the history of the CPC and our country, and guide them to develop a correct view of history.

\subsection{Problems Existing in Party History Education in Colleges and Universities}

The Party history education in institutions of higher learning can greatly help contemporary college students improve their ideological and political quality and strengthen the patriotism, but we can still find some problems that need to be solved in the process of implementing the Party history education in institutions of higher learning. First of all, the theoretical education is not fully implemented, for example, the Party history education focuses the story and key events of revolutionary history, while it lacks the exchange and discussion on the theoretical achievements of the Party in the course of historical development [3]. The second problem is the interference of network information. Some vulgar and entertaining contents released in network have hindered students from getting correct Party history education, and this not only affects students' political attitude, but also has negative effects on their socialist ideology. The last problem is about the traditional teaching method. The Party history education shall not be limited to the classroom education, and diversified ways and channels shall be used to consolidate the achievements of the Party history education in institutions of higher learning and increase publicity efforts.

\section{SIGNIFICANCE OF MARXIST SOCIAL SCIENCE METHODOLOGY TO PARTY HISTORY EDUCATION IN COLLEGES AND UNIVERSITIES}

The social science methodology is a methodology taking social science as the research object; while the Marxist social science methodology is a methodology system established based on dialectical materialism and historical materialism, and has rich contents, including practice-based research methods, social system research methods, social contradiction research methods, world history research methods, etc. In addition, as an open system, it enriches and develops itself by means of constantly summarizing the historical experience of socialism and absorbing and drawing lessons from all achievements of human civilization [4].
The Party history education in institutions of higher learning is one of the main channels for carrying out ideological and political education. For college students who learn the Party history, it is helpful to guide these students form a correct view of history, carry forward the red spirit and inherit the red gene. The history of the CPC is deemed as one of the important research directions in the field of Chinese philosophy and social science, so the Party history education in institutions of higher learning shall be offered under the guidance of Marxist philosophy principles and by flexibly using the Marxist social science methodology, aiming to help students get familiar with the historical development process, summarize the historical experience, and constantly adopt innovative ways and means of the Party history education in institutions of higher learning.

\subsection{Be Helpful for the Students to Form a Correct View of Party History}

President Xi Jinping emphasized that: "To establish a correct view of the Party history, historical materialism is the fundamental way for the communists to understand and master the history. If the view of history is not correct, we will not be able to achieve the purpose of learning and education, and more seriously, we will get confused and cause confliction between purpose and act." [5] Marxist social science methodology contains profound expressions on historical process and historical development etc., and we shall guide students to take historical materialism as a foothold, adopt historicism methods to realize close combination between the content of the Party history education and the historical background, and help students form a correct view of the Party history, have an accurate understanding of the historical development of the Party, and enhance the sense of identity with the $\mathrm{CPC}$ of the students institutions of higher learning.

\subsection{Be Helpful to Resist the Influence of Bad Ideology}

Along with the rapid development of the Internet technology, the network consensus has increasingly deeper influence on the students in institutions of higher learning, for example, the bad ideology such as historical nihilism has a negative impact and influence on the values and historical views of the students in institutions of higher learning, so it is required to guide students to learn and use Marxist social science methodology to correctly analyze historical events and view historical problems, help them take the right stand, viewpoints and methods to resist the influence of historical nihilism, and build a upright and positive ideological environment for the students in institutions of higher learning. 


\subsection{Be Helpful to Strengthen the Teaching Effect of Ideological and Political Theory Course}

For current ideological and political theory courses offered in institutions of higher learning, the main contents of the Party history learning and education undertaken in each course are not clearly specified, as a result of which, the students have to study the Party history in a fragmented manner and cannot form a complete knowledge hierarchy. In the process of the Party history education, in addition to listing the contents of the CPC history, it shall analyze and explain the contents from the relevant perspective of Marxist philosophy, adopt flexible methods to integrate the Party history education with the original ideological and political theory courses, to avoid being limited to the single course teaching, as well as shall dig out the course contents on the Party history in a holistic and systematic way, so that the Party history education can be integrated into the overall curriculum system of ideological and political theory course and strengthen the actual teaching effect.

\section{APPLICATION OF MARXIST SOCIAL SCIENCE METHODOLOGY IN PARTY HISTORY EDUCATION IN COLLEGES AND UNIVERSITIES}

\subsection{Application of Marxist Social Science Methodology Fundamentals in Party History Education in Colleges and Universities}

\subsubsection{Objectivity Principle}

The objectivity principle refers to research based on essence of the things while using Marxist social science methodology, which disapproves the subjective assumptions. In terms of the study of the Party history, it shall focus on the objectivity principle, understand history as what it originally looks like, and in the process of carrying out the Party history education in institutions of higher learning, "restore" the history as much as possible, by means of taking good use of teaching materials, books and other materials as well as organizing students to visit sacred place for the revolution, participate in activities in memory of revolutionary heroes, visit the Party history exhibition halls, etc., so that we are able to carry out the Party history education through various channels, and let the students experience what they can't feel in the classroom, as well as let students know the historical facts in a more completely and objectively manner from different perspectives.

\subsubsection{Subjectivity Principle}

The subjectivity principle refers to the observation and analysis of the object from the perspective of human beings with the human beings as the subject. For Marxist social science methodology, it shall strive to reveal the great role of the people in creating history and adhere to the fundamental principle of people-centered. "The people are the creators of history and the real heroes." [6] In the process of carrying out the Party history education in institutions of higher learning, it is required to fully reveal the historical role of the people, help students realize the dominant position of the people from the historical process of the Party, adhere to the historical viewpoint of the masses and disapprove the historical viewpoint of heroes.

\subsubsection{Integrity Principle}

Nothing exists solely on its own. The integrity principle focuses on the role played by the entire system in the process of analyzing and handling the problems. The key of the principle is to deal with the relationship between the whole and the part, including the relationship between human society and nature, the relationship between individuals and society, the relationship between social phenomena and the overall social movement, etc. In the process of the Party history education in institutions of higher learning, it shall properly master the relationship between macro historical background, specific historical events and historical figures, as well as shall guide students to put themselves into the overall historical environment for research and learning, instead of taking a certain historical event or historical figure as an isolated thing.

\subsubsection{Specificity Principle}

Ultimately, the specificity principle refers to specific analysis of specific issues based on practical and realistic viewpoint. To better carry out the learning and education of the Party history, the institutions of higher learning shall guide the students to study the Party history in a three-dimensional manner and handle the relationship between abstraction and concreteness. In terms of the historical issues, they shall be viewed by following the rigorous attitude, based on the background of the times, social, political and economic system, cultural development level etc. at the time, and combined with historical clues such as causes and effects, to make the historical events unrelated to boring abstract definitions, enrich the historical events, and highlight the specificity of the Party history education, instead of one-sided analysis of historical phenomena. 


\subsubsection{Development Principle}

The development principle refers to view of issues from a long-term and development perspective, analysis of the issues at the strategic commanding height, make overall arrangement, to avoid view of the issues from a metaphysical view. Currently, we are facing a changeable international environment and the world is undergoing a great changes unseen in a century. Under such historical background, it is a good time to carry out the Party history learning and education. The Party history education in institutions of higher learning shall be carried out based on the development principle, so as to teach students to review the struggle history of the CPC since its founding and summarize the historical experience of the Party, and guide them to look forward to the future development trend from the viewpoint of historical materialism, gain studying-related enlightenment from history, and make preparations to realize their future plans and objectives.

\subsection{Application of Specific Methods of Marxist Social Science Methodology in Party History Education in Colleges and Universities}

\subsubsection{Application of Practice-based Research Methods}

Practice is the basis for the human cognition generation and development. The practice-based research method refers to a method for analyzing the relationship between theory and practice to summarize the practical experience and therefore guide the learning and research. The practice-based research method shall be adopted in the process of the Party history education, to explain to the students that scientific theory is the result of refined and sublimed practical experience. It is required to focus on revealing the main development line of the Party's innovative theory, i.e., the historical context of theoretical development from Mao Zedong Thought to the theoretical system of socialism of Chinese characteristics, and this is the valuable theoretical achievement obtained by the CPC in the practical process of revolution, construction and reform, by combining the basic principles of Marxism with China's actual situation and summing up both positive and negative experiences.

\subsubsection{Application of Social Contradiction Research Methods}

Contradiction is the driving factor that promotes the social development. The social contradiction research method focuses on the analysis of complex contradictory relations existing in the social system, and with focus on the law of unity of opposites in materialist dialectics, it makes further research on social and historical problems from the perspective of contradiction analysis, to explore and find ways and means to solve contradictions. In the process of carrying out the Party history education in institutions of higher learning, the following two aspects shall be emphasized. Firstly, it is about the analysis and judgment of the CPC on the changes in major contradictions in Chinese society, which is the main line of contradiction analysis that runs through the main line of history. A series of correct principles and policies of the Party are put forward based on a correct understanding of the main social contradictions in China, so in the ever-changing social progress, we can deal with the changes in the main social contradictions by insistently adopting the contradiction analysis methods of the theory that everything has two aspects and key aspect. Secondly, it is about the dialectical relationship between the basic social contradictions and the main social contradictions. In the social development process, the contradiction between productive forces and the relations of production and the contradiction between economic basis and superstructure form the basic contradiction of human society, whose existence determines the existence of major social contradictions, and the settlement of major social contradictions can continuously promote the settlement of basic social contradictions [7], so we shall guide students to fully realize the continuous development process of the Party during the correct understanding such dialectical relationship, as well as some historically significant principles and policies formulated by the Party.

\subsubsection{Application of Social Process Research Methods}

The social process research method is a method that provides the scientific guidance for the study of social and historical phenomena based on the contents of Marxist theory in terms of social development process and law. The social and historical process develops with the characteristics of continuity and discontinuity, progress and setbacks. While carrying out learning and education of the Party history, the institutions of higher learning shall flexibly use social process research method. On one hand, it shall guide students to systematically learn the development process of the Party, which is the basic requirement for the Party history education, and make them realize that the historical development of the Party is in line with the law of unity of progress and setbacks. The development of social history is not smooth and linear; the Party will inevitably encounter setbacks in the process of leading the Chinese people for revolution, reconstruction and reform. The development process of socialist society is also tortuous, but we must adhere to the law of unity of progress and setbacks and learn the entire Party's history so as to grasp the overall situation of historical development, firmly believe in the progress, as well as recognize the setbacks and turns on the way of 
development and get fully prepared. On the other hand, we shall teach students to fully learn the historical development process of the Party history education course. The CPC has adopted various forms of the Party history education practice, summarized a lot of valuable historical experiences. For example, from its own development path, the Party history learning and education runs through all historical periods since the founding of the Party, from the preliminary exploration stage in the new democratic revolution period, the concentrated development stage in the socialist revolution and construction period to the continuous development and innovation stage since the 18th National Congress of the CPC, which is deemed as is a vivid self-construction history of the Party, reflects how the Party has carried out the learning and education of the Party history in different historical periods and embodies the spirit of self-targeted revolution of the CPC [8]. It can help the educators to explore the innovation points of the Party history education from the perspective of social process research, describe the development process of the Party history education and refine the value connotation of the Party history education, as well as can help the students in institutions of higher learning to improve their ideological and moral quality and historical quality, develop their strong will, and cultivate their basic discipline knowledge and capabilities.

\section{CONCLUSIONS}

In conclusion, Marxist social science methodology is a systematic methodology discipline in social history research field, and Party history education in colleges and universities is a systematic project, involving all aspects of educators and educatees; Therefore, the relevant theories of Marxist social science methodology can be applied to the implementation process of Party history education in colleges and universities, under the guidance of scientific methodology, it can strengthen the pactical effect as well as enrich the ways and methods of Party history education in colleges and universities . So, we shall flexibly apply Marxist social science methodology, adhere to its guiding position, and better integrate it into all aspects of Party history education in colleges and universities.

\section{REFERENCES}

[1] Xi Jinping. Speeches at the Party History Learning and Education Mobilization Meeting [J]. Qiushi, 2021 (07). (In Chinese)

[2] Li Peipei. Strengthening and Improving the Learning and Education of the CPC History among College Students [D]. Ya'an Sichuan Agricultural University, 2013. (In Chinese)

[3] Qin Jichun, He Yanxin. Practical Significance and Educational Strategy of College Students Studying the CPC History Theory under the New Situation [J]. Leading Journal of Ideological \& Theoretical Education, 2016 (08): 69-72. (In Chinese)

[4] Editorial group of this article. Marxism and Social Science Methodology (2018 Edition) [M] Beijing: Higher Education Press, 2018: 5-9. (In Chinese)

[5] Xi Jinping. Speeches at the Party History Learning and Education Mobilization Meeting [J]. Qiushi, 2021(07). (In Chinese)

[6] Xi Jinping. On the History of the Communist Party of China [M]. Beijing: Central Party Literature Press, 2021; 119-120. (In Chinese)

[7] Wang Xiangqing, Yang Zhenzhen. Study and Analysis on of Basic Social Contradictions and Major Social Contradictions and Their Dialectical Relations [J]. World Philosophy, 2019 (04): 15-23. (In Chinese)

[8] Chen Rongwu. Historical Investigation and Development Direction of the Party History Learning and Education [J]. Ideological \& Theoretical Education, 2021(03): 76-82. (In Chinese) 